\title{
Correction to: (Sea)ways of Perception: an Integrated Maritime-Terrestrial Approach to Modelling Prehistoric Seafaring
}

\section{Stephanie L. Blankshein ${ }^{1}$ (D)}

Published online: 6 November 2021

(c) Springer Science+Business Media, LLC, part of Springer Nature 2021

\section{Correction to: Journal of Archaeological Method and Theory https://doi.org/10.1007/s10816-021-09536-4}

The statement of Availability of Data and Material read as follows:

All data supporting this study are openly available from the University of Southampton repository at https://doi.org/10.5258/SOTON/D1974

The original version has been corrected.

Publisher's Note Springer Nature remains neutral with regard to jurisdictional claims in published maps and institutional affiliations.

The original article can be found online at https://doi.org/10.1007/s10816-021-09536-4

Stephanie L. Blankshein

s.blankshein@soton.ac.uk

1 Centre for Maritime Archaeology, University of Southampton, Southampton, UK 